\title{
Analysis on Perceived Value of Different Services by Online Group Buying in China
}

\author{
Qinfang $\mathrm{Li}^{1, \mathrm{a}^{*} \text {, Shixiang Zhang }}{ }^{2, \mathrm{~b}}$ \\ ${ }^{1}$ School of Economics \& Management, Tongji University, Shanghai, 200092 \\ ${ }^{2}$ Office of Scientific Research, Shanghai University of Electric Power, Shanghai 200090 \\ aliqinfang@163.com, bsxwh@126.com
}

\begin{abstract}
Keywords: Group Buying, Perceived Value, Non-monetary Costs
Abstract. By classifying the services provided by online group buying website in China into 3 types, restaurant service, entertainment service, travel and hair body care service, the paper aimed to examine the differences of the perceived value for those services. Empirical data was collected from a survey of online group buying users in China. The results of the empirical analysis indicate that customer's perceived value vary from service by service. There is a significant difference between entertainment service and other two kinds of services. Perceived value of the restaurant service is not significantly different from the Travel and hair body care service.
\end{abstract}

\section{Introduction}

As one of the popular online business models, online group buying has been in vogue for many years in various industries. The Internet provides a natural platform to facilitate group buying. It facilitates the exchange of information between buyers and sellers quickly and without the limitations of time and space. Group buying benefits sellers by offering lower marketing costs and coordinated distribution channels. It also benefits buyers who enjoy lower costs for product purchases. Online group buying was perceived as one of the most innovative business models of e-commerce, and has been employed by many companies. Although some early pioneers failed, online group buying has been reviving in Europe, North America and Asia in recent years ${ }^{[1]}$.

In 2010, we have seen the emergence of new and vibrantly successful online group buying markets in China, most popular among them include lashou (www.lashou.com), meituan (www.meituan.com), nuomi (www.nuomi.com), dianping (www.dianping.com), etc. More than 1,000 Chinese copycats of Groupon came into existence in the twinkle of an eye in $2010^{[2]}$. With even once more than 6000 group buying websites which 4670 of them has been closed, the group buying in China experienced failure, combination and then became even more matured (Investigation Report of Online Group Buying in China in 2013 (Jan.-June.), EC100.com). According to the report (Tuan800, 2012), the eighth month of 2012 brought 270,000 daily deal offers to Chinese consumers, and the turnover of that month reached 2.11 billion RMB (around 335 million USD).

Tang ${ }^{[3]}$ has reported that online group buying in China are occurring with a blend of online and offline operations, where prices are known only when a consumer commits to a purchase, customer acquisition occurs through word-of-mouth, online group shopping is viewed as a leisure activity. The purchased service is provided by offline operations after the online group buying. Since different service has its own characteristics, for example, the cost of money, time, service process, expectations from the customer are different. Whether or not those different services will lead to different customer's perceived value? Since group buying is driven by the demand of buyers, a central issue for group buying mechanism is how to improve the satisfaction of buyers. Perceived value influences satisfaction of the customer ${ }^{[4]}$. We try to compare the customer's perceived value on different types of service provided by group buying. 


\section{Theoretical Background and Hypothesis}

\section{Customer's Perceived Value}

The perceived value is defined as "the consumer's overall assessment of the utility of a product (or service) based on perceptions of what is received and what is given" ${ }^{[5]}$. Customer's perceived value can be analyzed with a multidimensional scale. It can be defined from the perspectives of money, quality, benefit, and social psychology ${ }^{[6]}$. The Monetary perspective indicates that value is generated when less is paid (such as by using coupons or promotions) for goods ${ }^{[7]}$. In other words, it is the concept of consumer surplus in economics. In perspective of quality, value is the difference between the money paid for a certain product and the quality of the product ${ }^{[7]}$. That is, when less money is paid for a high quality product, positive perceived value will be created. The benefit perspective indicates that perceived value is customers' overall evaluation of the utility of perceived benefits and perceived sacrifices ${ }^{[5]}$. In other words, consumers may cognitively integrate their perceptions of what they get and what they have to give up in order to obtaining goods. However, the sacrifice means more than the money paid for a certain goods. Non-monetary costs, such as transaction cost, search cost, negotiation cost, and time incurred during the purchase, should also be included ${ }^{[4]}{ }^{[5]}$. In our study, perceived value is the evaluation of the benefits of a service by customers based on their advance sacrifices and perceived service when they enjoy online group buying services.

\section{Service Types Provided by Online Group Buying}

The service industry, as a whole, covers many fields which have a close relationship with the people's daily life, such as tourism service, financial services, hotel services, logistics services, hospitality services, etc. Currently, besides the physical products, the online group buying websites in China offer mainly non physical service products, especially local services for their customers. According to "Investigation Report of Online Group Buying in China in 2013 (Jan.-June.), EC100.com", besides the $53 \%$ physical product transaction, main non-physical services provided by Chinese online group buying websites can be classified into several kinds: restaurant service accounted for 19\%, ranking as the first; entertainment $13 \%$ as the second; travel and tourism 9\%; hair and body care 4\%; other services $2 \%$. The first one is restaurant service, such as restaurant reservation, beer and drink consuming, etc. The second kind of service provided is entertainment and leisure activities, which includes film tickets reservation, Bowling and swimming sports, and so on. The third is travel and tourism, ticket and hotel reservation, etc. The fourth is hair and body care service. Other services include some daily life services, such as photographing for new couples and Children. Considering that the third and fourth one together accounts for $13 \%$ of the market share, almost near the first two services, we try to divide and discuss three types of online group buying services in China: restaurant service, entertainment service, travel and hair body care service.

\section{Customer's Perceived Value and Service Type}

As far as product is concerned, differences in product characteristics and the implications of such differences for marketing and operations have been dealt with extensively in the extant literature ${ }^{[8]}$. In the context of electronic B2C transactions, Kauffman and Walden ${ }^{[9]}$ observed that "since the new economics of electronic commerce depends to a great degree on the characteristics of the products transacted on the Internet, it is important to understand the nature of these products and their value to the consumer." Service can be view as one kind of product, invisible product. But service is different as product. There is a substantial variation in service delivery ${ }^{[10]}$. As captured in Langeard and Englier's "servuction" model ${ }^{[11]}$, service firms and the service production process can be divided in two parts: one that is visible to the consumer and a second that is invisible (the "technical core"). McDougall and Levesque ${ }^{[12]}$ proposed that customers may be happy with the service provided(the core), how it is provided(the relational) and overall be satisfied with the service, but not feel that they have received their money's worth. Group buying consumers have to face the possibility of an uncertain outcome ${ }^{[13]}$. Since invisible parts of different service varies from each other, we suppose that customer's perceived value differs from the service type. 
As far as entertainment service such as film ticket, sport activities reservation is concerned, customers have more idea about the core service and their sacrifice in terms of money cost is relatively low compared with the other two. Consequently, customer's perceived value for entertainment services are likely to be higher relative to that of other two services. On the other hand, online group buying of hair care, body care service tends to be in relatively more invisible, customers have not only time, money sacrifice but also perhaps personal image risk. Consequently, customer' perceived value are likely to be relatively lower. Restaurant service, as the moderate one, customer's perceived value is likely to be the moderate.

Thus, our hypothesis is proposed as following: customer' perceived value will differ from the service types provided by online group buying.

\section{Research Design and Analysis}

\section{Data Collection}

Data for the study were collected from customers on their actual group buying experience. The data were collected by snow ball methods. Firstly investigation questionnaire were sent to several MBA students by Email. Then they forwarded the questionnaire to their friends and relatives. Finally, 91 of questionnaires were collected but only 89 were usable. Among the samples collected, female respondents $(59.6 \%)$ were the majority. The respondents was distributed with ages ranging from 18 to $35(82 \%)$ and more than $35(17 \%)$. Most of them were the users of lashou, taobao, dianping, meituan. In terms of group buying use time, over $87 \%$ of them have used group buying services for more than 2 month. Most of the respondents have group buying experience on different services, therefore almost each provided more than one sample data. We finally got 261 samples by all their questionnaires.

We adopted measurement items for perceived value from Ying-Feng Kuo et al. ${ }^{[6]}$, with some modification, which is shown by Table 1. All three items were measured using a seven point Likert scale with 1 indicating "strongly disagree" and 7 indicating "strongly agree" for the perceived value of their online group buying services.

Table 1. Items to measure customer's perceived value

\begin{tabular}{|c|c|c|}
\hline Item & Measurement & Reference \\
\hline PV1 & I feel I am getting good service for a reasonable price. & Cronin et al. ${ }^{[4],[14]}$ \\
\hline PV2 & $\begin{array}{l}\text { Using the service provided by the offline service supplier is } \\
\text { worth for me to sacrifice some time and efforts. }\end{array}$ & Tung $(2004)^{[15]}$ \\
\hline PV3 & $\begin{array}{l}\text { Compared with others, it is wise to choose this online group } \\
\text { buying website and the offline service supplier. }\end{array}$ & Wang et al. ${ }^{[16]}$ \\
\hline
\end{tabular}

\section{Results and Analysis}

Our empirical testing of hypothesis involved factor analysis followed by a one way univariate analysis of variance (ANOVA). Factor analysis of the three variables representing customer's perceived value yielded a single factor with eigenvalue greater than 1, accounting for $83.8 \%$ of variance in the underlying variables. The loadings for the three variables are presented in Table 2 . Factor scores for the 261 study sample were obtained and these scores are used to measure customer's perceived value. 
Table 2. Results of factor analysis of customer's perceived value variables

\begin{tabular}{c|c}
\hline Perceived Value Variables & Factor Loadings \\
\hline PV1 & 0.891 \\
\hline PV2 & 0.932 \\
\hline PV3 & 0.923 \\
\hline Eigenvalue & 2.515 \\
\hline Percentage of variance & $83.828 \%$ \\
\hline Cumulative \% of variance & $83.828 \%$ \\
\hline
\end{tabular}

In the next step, we conducted a one-way ANOVA to examine if customer's perceived value varies from the service type, as posited in our hypothesis. We checked and found no significant departures from the assumptions of normality. ANOVA results are presented in Table 3 . The results suggest that statistically significant differences exist among the three service types with respect to customer's perceived value. Further, pair wise comparisons of the means reveal that: there exists a significant difference between customer's perceived value with entertainment services and restaurant services, also significant difference between entertainment services and hair care and body care services. However, customer' perceived value is not significantly different from restaurants to hair care and body care services. Therefore, the results indicate that the hypothesis has been verified: customer' perceived value differs from the service type provided by online group buying.

Table 3. Results of one-way anova examining the effect of service type on customer's perceived value

\begin{tabular}{c|c|c|c|c|c}
\hline & $\begin{array}{c}\text { Sum of } \\
\text { Squares }\end{array}$ & Df & $\begin{array}{c}\text { Mean } \\
\text { Square }\end{array}$ & F & Sig. \\
\hline Between Groups & 6.307 & 2 & 3.154 & 3.288 & .039 \\
\hline Within Groups & 247.422 & 258 & .959 & & \\
\hline Total & 253.729 & 260 & & & \\
\hline
\end{tabular}

\begin{tabular}{l|l|l|l|l}
\hline \multicolumn{1}{c|}{ Product types compared } & \multirow{1}{c}{$\begin{array}{c}\text { Mean } \\
\text { Difference } \\
(\mathrm{I}-\mathrm{J})\end{array}$} & $\begin{array}{c}\text { S.E. of } \\
\text { difference }\end{array}$ & \multicolumn{1}{c}{$\begin{array}{c}\text { P- } \\
\text { Value }\end{array}$} \\
\cline { 1 - 3 } $\begin{array}{l}\text { Entertainmen } \\
\mathrm{t} \text { Service }\end{array}$ & Travel, Hair Body care Service & $0.3551(*)$ & .1518 & .020 \\
\hline $\begin{array}{l}\text { Entertainmen } \\
\mathrm{t} \text { Service }\end{array}$ & Restaurant Service & $0.3274(*)$ & .1514 & .031 \\
\hline $\begin{array}{l}\text { Restaurant } \\
\text { Service }\end{array}$ & Travel, Hair Body care Service & 0.0276 & .1439 & .848 \\
\hline
\end{tabular}

* The mean difference is significant at the .05 level

\section{Discussion and Implication}

The findings of this study indicate that customer's perceived value vary from services provided by online group buying. According to the mean difference, customer's perceived value of entertainment service is highest. There are certain reasons for that for current group buying situation in China. For one thing, one of the most popular entertainment service ordered in China is film ticket. For this kind of service, consumers have relatively complete information about the service, when, where and how is the film. However, for other services, such as restaurant and hair care, the service is more invisible and variable to consumers. How about the taste of the dishes? How they will be served? How long to wait to be served? How is the process about the body care? How about the quality of the body care product used? Consumers have less or no idea about that when they order the service online. Only after the offline service can they know about the whole service. The service may have a great gap with their 
expectation. Therefore, perceived value varies from entertainment service to other two services, restaurant services, travel and hair body care services. For the second thing, group buying in China need to be further normalized. Policies and rules for setting and managing a group buying website is not complete, which lead to the situation that some group buying website and service suppliers are not responsible for the consumers. In order to attract more consumers, the service suppliers provide low prices on internet. However, to make profit, some suppliers simplify the service process or reduce the service quality to group buying customers. One of the main complaints of group buying is that the online group buying consumers receive unfair treatment compared with ordinary offline consumers.

The research has some implications for effectively managing online group buying in China. Firstly, online web sites should consider cooperating with their service suppliers which are trustworthy. Offline service suppliers should provide consistent and good service as ordinary situation. Consumer satisfaction and trust are the strongest predictors of intention to engage in online group buying ${ }^{[17]}$. Experimental results ${ }^{[13]}$ suggest that the levels of procedural fairness and price fairness perceived by consumers have significant positive effects on their intention to participate and bid in online group-buying. Secondly, information about services, especially hair body care which has an information asymmetry on consumer, should be more complete. What's more, evaluation mechanism can be introduced. For example, user's feedback can also be used as an evaluation of some service suppliers or even some services. However, our research has its limitations. The classification of service type in our research is based on the online group buying market share, later researchers can discuss the influence of service types on perceived value based on more scientific and reasonable classification scheme. Furthermore, besides the relationship of perceived value and service type by group buying, the relationship of perceived service value by offline purchase and online group buying can be further compared and researched on.

\section{Conclusions}

By classifying different service types provided by Chinese group buying suppliers, we compared the customer's perceived value for those services. Our research indicates that the perceived value of entertainment has significant differences as compared with restaurant services and hair care and body care services. Among the three kinds of services, perceived value of entertainment service is highest, then restaurant services and finally hair care and body care services. But the result shows no significant difference between restaurant services and hair care and body care services.

\section{References}

[1] J. Chen, X. Chen, R.J. Kauffman, X. Song: Should we collude? Analyzing the benefits of bidder cooperation in online group-buying auctions, Electronic Commerce Research and Applications, 8 (4), 2009,pp.191-199.

[2] Ziqiong Zhang, Zili Zhang, Fan Wang, Rob Law, Dechao Li. Factors influencing the effectiveness of online group buying in the restaurant industry, International Journal of Hospitality Management, Vol. 35, 2013, pp. 237-243.

[3] Tang, C. S. United we may stand. Sloan Management Review. May 12, 2008

[4] Cronin, J. J., Brady, M. K., \& Hult, G. T. M. Assessing the effects of quality, value, and customer satisfaction on consumer behavioral intentions in service environments. Journal of Retailing, 76(2), 2000, pp. 193-211.

[5] Zeithaml, V. A. Consumer perceptions of price, quality and value: A mean send model and synthesis of evidence. Journal of Marketing, 52(3), 1988, pp. 2-13.

[6] Ying-Feng Kuo, Chi-Ming Wub, Wei-Jaw Deng. The relationships among service quality, perceived value, customer satisfaction, and post-purchase intention in mobile value-added services, Computers in Human Behavior 25, 2009, pp. 887-896.

[7] Bishop, W. R. Jr. Competitive intelligence. Progressive Grocer, 63(3), 1984, pp. 19-25. 
[8] Sriram Thirumalai1, Kingshuk K. Sinha. Customer satisfaction with order fulfillment in retail supply chains: implications of product type in electronic B2C transactions, Jounal of Operational Management, 23, 2005, pp. 291-304.

[9] Kauffman, R.J., Walden, E.A. Economics and electronic commerce: survey and research directions. International Journal of Electronic Commerce, 5 (4), 2001, pp. 5-28.

[10] Frei, F. X., Kalakota, R., Leone, A. J., \& Marx, L. M.. Process variation as a determinant of bank performance: evidence from the retail banking study. Management Science, 45, 1999, pp. 1210-1232.

[11] Bateson, J. E. G., \& Hoffman, K. D. Managing services marketing. Forth Worth, TX: Dryden Press, 1999

[12] McDougall, G.H., \& Levesque, T. Customer satisfaction with service: Putting perceived value into the equation. Journal of Services Marketing, 14(5), 2000, pp. 392-405.

[13] Robert J. Kauffman, Hsiangchu Lai, Chao-Tsung Ho. Incentive mechanisms, fairness and participation in online group-buying auctions, Electronic Commerce Research and Applications, 9(3), 2010, pp. 249-261.

[14] Cronin, J. J., Brady, M. K., Brand, R. R., Hightower, R., \& Shemwell, D. A crosssectional test of the effect and conceptualization of service value. The Journal of Service Marketing, 11(6), 1997, pp. 397-415.

[15] Tung, L. L. Service quality and perceived value's impact on satisfaction, intention and usage of short message service (SMS). Information Systems Frontiers, 6(4), 2004, pp. 353-370.

[16] Wang, Y., Lo, H. P., \& Yang, Y. An integrated framework for service quality, customer value, satisfaction: Evidence from China's telecommunication industry. Information Systems Frontiers, 6(4), 2004, pp. 325-344.

[17] Wen-Lung Shiau, Margaret Meiling Luo. Factors affecting online group buying intention and satisfaction: A social exchange theory perspective. Computers in Human Behavior, 28(6), 2012, pp. 2431-2456. 